\title{
Impact of training for site staff recruiting into trials of rare skin diseases: experiences from stop gap and blister
}

\author{
Eleanor Mitchell, Lelia Duley, Hywel Williams, Diane Whitham \\ From 2nd Clinical Trials Methodology Conference: Methodology Matters \\ Edinburgh, UK. 18-19 November 2013
}

\section{Background}

Nottingham Clinical Trials Unit is co-ordinating two RCTs in rare skin diseases: one recruited people with pyoderma gangrenosum (STOP GAP), the other people with bullous pemphigoid (BLISTER). Sites were initially identified via the UK Dermatology Clinical Trials Network (http://www.ukdctn.org) without using formal site selection criteria. Many sites were naive, having not recruited to trials previously.

Training of site staff used a variety of methods including investigator meetings, face-to-face site initiation meetings, telephone training and remote training using a DVD. This presentation will describe recruitment and data quality by trial site, and how these relate to the type of training.

\section{Methods}

Training was assessed based on initial training, rather than training of new staff who joined the trial later. Recruitment by site and trends in recruitment were compared for sites having different forms of training. Completeness of data collection, number of data queries, and timeliness of returns for data and queries were also compared.

\section{Results}

Across the 2 trials, there were 67 UK sites. STOP GAP recruited 121 participants over $3 \frac{1}{2}$ years. BLISTER aims to recruit 256 participants by the time recruitment closes in September 2013. Results will be presented and discussed.

\section{Conclusion}

Recruitment and data quality are key elements of efficient trial conduct. Results from this study will contribute to

University of Nottingham, Nottingham, UK understanding of how training of site staff might improve study conduct for trials involving naive sites and those involving participants with rare diseases.

Published: 29 November 2013

doi:10.1186/1745-6215-14-S1-P134

Cite this article as: Mitchell et al:: Impact of training for site staff recruiting into trials of rare skin diseases: experiences from stop gap and blister. Trials 2013 14(Suppl 1):P134.
Submit your next manuscript to BioMed Central and take full advantage of:

- Convenient online submission

- Thorough peer review

- No space constraints or color figure charges

- Immediate publication on acceptance

- Inclusion in PubMed, CAS, Scopus and Google Scholar

- Research which is freely available for redistribution
C Biomed Central

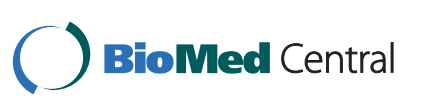

(C) 2013 Mitchell et al; licensee BioMed Central Ltd. This is an Open Access article distributed under the terms of the Creative Commons Attribution License (http://creativecommons.org/licenses/by/2.0), which permits unrestricted use, distribution, and reproduction in any medium, provided the original work is properly cited. 